\title{
Comparing Professional Self-Confidence: Opinions of Lithuanian, Ukrainian and Finnish Teachers
}

\author{
Tetiana Ponomarenko, MA \\ Vytautas Magnus University, Kaunas, Lithuania
}

doi: 10.19044/esj.2017.v13n19p70 URL:http://dx.doi.org/10.19044/esj.2017.v13n19p70

\begin{abstract}
The current study reports findings of quantitative investigation of the opinions of Lithuanian, Ukrainian and Finnish teachers on their perceived professional self-confidence with a sample of 393 practicing teachers. Teachers' self-esteem, self- and collective efficacy were examined as components of teachers' professional self-confidence. Collective efficacy beliefs were measured in terms of teachers' subjective perception of efficacy of school community members, namely, the principal, colleagues, students and their parents. The results indicated that Finnish teachers have a significantly higher level of professional self-esteem, while Lithuanian teachers indicated a lower level, and Ukrainian - the lowest. There is no significant difference between self- and collective efficacy of Lithuanian and Finnish teachers, while Ukrainian teachers scored significantly lower. Consequently, Finnish teachers have the highest level of professional selfconfidence, while Lithuanian teachers have an average level, and Ukrainian teachers have the lowest. Lithuanian, Ukrainian and Finnish teachers indicated different patterns of their perceptions of the extent to which members of the school community meet their obligations.
\end{abstract}

Keywords: Self-confidence, teacher's professional self-confidence, selfesteem, self-efficacy, collective efficacy

\section{Introduction}

Changes in society and in the world of work, the growing need of lifelong skills, combined with reforms of education policies, create challenges for teachers and sometimes cause stressful working conditions, affecting teachers' beliefs about their own abilities to teach and value themselves as professionals. According to general Teaching Council of England, the majority of teachers claimed being disrespectfully regarded by the society, and more than half of them reported about absence of respect from government and students' parents. Moreover, teachers reported about the crisis of professional self-confidence, feeling themselves untrusted, 
underappreciated and over-controlled by the external institutions, and believed being badly represented by the media (Hargreaves et al., 2007). Such results are difficult to believe, as the educational system of the UK is highly efficient and recognized worldwide. Therefore, the research problem naturally arouse from the concern about teachers' self-confidence in the countries which have comparatively less efficacious educational systems, such as Ukraine and Lithuania. On the basis of the personal experience of the researcher, teachers in these countries share similar beliefs as the UK teachers, however, the level of their professional self-confidence has not been investigated before. At the same time, Finnish educational system with its internationally-recognized high quality innovating school education and trustful treatment of teachers has been recognized as one of the best in the world. Consequently, Finnish teachers might enjoy a high level of the professional self-confidence. Hence, the research problem is the assumption that Lithuanian, Ukrainian and Finnish teachers might have different levels of professional self-confidence.

The study of teachers' self-confidence has gained a significant attention from researchers over the past two decades because it influences the motivation and behavior of teachers, student achievement and performance (Shrauger \& Schohn, 1995; Postareff \& Lindblom-Ylane, 2011; Sadler, 2013). Teacher's self-confidence depends on competencies and experience (Sadler, 2013), autonomy and freedom in decision-making process (Paradis, Lutovac \& Kaasila, 2015), self-worthiness and beliefs in own capacities to succeed (Wesson, 2003). In addition, it is linked to the concepts of self-efficacy and self-esteem (Caprara et al., 2003; Klassen \& Chiu, 2010; Peng, Schaubroeck \& Xie, 2015). However, very few studies were focused on conceptualizing the term of self-confidence (Shrauger \& Schohn, 1995; Holland, Middleton \& Uys, 2012), and less in known about the professional self-confidence of teachers and its components. In addition, the investigation and measurement of teachers' professional self-confidence of Lithuanian, Ukrainian and Finnish teachers have not been performed before. Thus, there is a lack of theoretical and practical research in the field of teachers' self-confidence, in terms of both, its conceptualization and measurement. Therefore, the goal of the current research is to analyze and describe the concept of teacher's professional self-confidence, measure and compare the average degrees of its components for Lithuanian, Ukrainian and Finnish teachers.

\section{Personal self-confidence and its components}

Personal self-confidence is a complex construct, which was conceptualized and measured differently by researchers. Personal selfconfidence is a positive or negative self-perception and certainty directed 
towards person's general capabilities (Paradis et al., 2015). Some researchers define self-confidence as a person's sense of competency and skillfulness, their perceived abilities to cope effectively with challenging situations (Shrauger \& Schohn, 1995), belief in person's competence to achieve certain goals (Carroll, Arkin \& Shade, 2011), abilities and certainty, based on knowledge and related to past performance and experience (Oney \& Oksuzoglu-Guven, 2015). Self-confidence may be expressed verbally (oral speeches, humor) or non-verbally (movement, facial expressions, body language), while self-efficacy and self-esteem are internal beliefs and feelings (Khan, Fleva \& Qazi, 2015).

The term "self-confidence" is often synonymized with two related terms - "self-efficacy" and "self-esteem"; thus, there is a need for their determination. Self-esteem refers to person's emotional reaction on his/her self-reflection and self-evaluation (Heatherton \& Wyland, 2003). Selfesteem includes self-confidence, being a part of a broader self-concept (Gecas, 1982), while self-efficacy is narrower and refers to a person's certainty with regard to his/her own capabilities and competency in task execution. The terms of "confidence”, "self-confidence”, "professional confidence" and "self-efficacy" were defined as "surrogate” and were used as synonyms by the researchers (Holland et al., 2012).

\section{The concept of teacher's professional self-confidence}

Personal self-confidence is a prerequisite for professional selfconfidence, and it is defined as a "dynamic, maturing personal belief held by a professional or a student” (Holland et al., 2012, p.222). In general, employees with high professional confidence perceive themselves as competent, capable in mastering work-related tasks and coping with professional challenges. Moreover, they are persistent and committed to accomplishment of their working duties, and are less likely to leave the profession (Clark, 2010). While employees with low professional confidence are uncertain about their own professional skills and competencies, highly rely on external feedback, are more likely to experience job-related stress and anxiety. Therefore, professionally self-confident teachers are committed and persistent, believe in their competency, abilities to master teaching tasks and cope with pedagogical challenges, feel emotional comfort in the working environment.

The present study suggests that self-confidence, in a broad sense, is the external visible expression and verification of person's inner evaluative belief - self-esteem, which was defined by Miller and Moran (2006) as worth-based and efficacy-based. The conceptualization of teachers' professional self-esteem as a broader and generic term for self-worth and self-efficacy is based on the theory of self-concept, described by Gecas 
(1982), where both self-worth and self-efficacy are evaluative aspects of self-esteem (Figure 1).

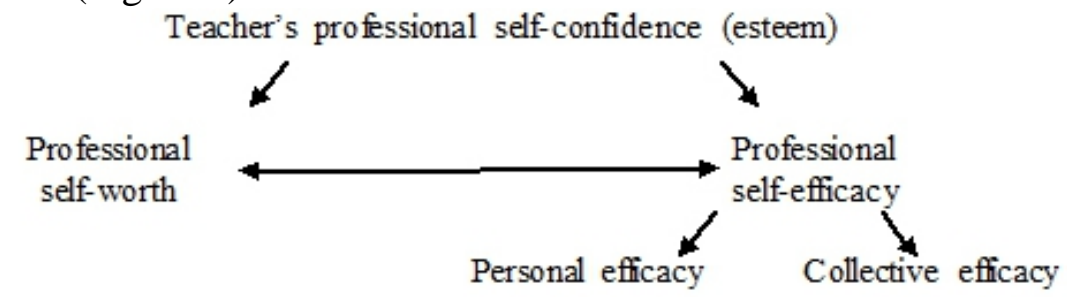

Figure 1. The concept of teacher's professional self-confidence

In addition, this study suggests the social nature of teachers' professional confidence, based on Bandura's social cognitive theory (1995), where the author introduced the idea of self-efficacy as a product of human relations, interactions and mutual direct or indirect influence. Hence, the impact of school environment and human interactions should not be omitted for teachers' professional confidence investigation. Therefore, teacher's professional self-confidence is the external (verbal, non-verbal) expression of teacher's inner subjective beliefs about his/her professional worth, certainty in their own and collective teaching competence and professional achievement. Consequently, if the teacher has a positive self-attitude, believes that he/she is professionally competent, certain about professional achievement, appreciated within the working environment and believes in efficiency of all school collective - such a teacher will behave and act confidently, demonstrating high professional achievement. At the same time, this definition contradicts the statement of Eison (1990) "To feel confident in the classroom the instructor must begin acting confidently", as teacher's confidence derives from deep inner beliefs, experience of success and efficiency of working (school) environment.

\section{Teacher's professional self-esteem}

The current study follows a two-dimensional structure of self-esteem, described by Miller and Moran (2006) and applied for measurement of selfesteem in school environment. Thus, self-esteem consists of self-worth (selfevaluation, recognition and respect from others) and self-competence or efficacy (task accomplishment, coping with challenges) and both constructs self-worth and self-efficacy, equally influence person's self-esteem. Teacher's professional self-esteem is an emotional response to evaluation of teacher's own professional achievement and teaching qualities, subjective perception of external recognition and appreciation by other members of school environment. 
Self-worth is the degree of individuals’ positive evaluation, feeling themselves valuable and capable. It is a positive self-view, related to selfacceptance and self-respect (Stets \& Burke, 2014). Thus, teacher's selfworth, as a part of the professional self-esteem, is a teacher's subjective feeling of satisfaction with self as a teacher, positive evaluation of his/her own professional qualities and achievement.

\section{Teacher's professional self-efficacy}

The person's sense of self-efficacy is the evaluative aspect of one's competence. The definition of teacher professional self-efficacy varies; however, most authors point common characteristics focusing on teachers' certainty about their own ability to affect students' behavior (Savolainen et al., 2012; Putman, 2012), accomplish teaching tasks successfully (TscannenMoran et al., 1998), persist facing work-related difficulties and stay in the teaching profession (Cheung, 2006). Skaalvik and Skaalvik (2007) identified teacher self-efficacy as a multidimensional construct, which relates to teacher's instruction skills, ability to adapt teaching mode to individual needs of students, enhance students' motivation and achievement, support the discipline, collaborate with colleagues or parents, cope with professional challenges and changes. Moreover, teachers' self-efficacy beliefs affect the effort teachers put into job-related activities, their persistence and enthusiasm to teaching (Skaalvik \& Skaalvik, 2007).

In social cognitive theory, introduced by Albert Bandura (1977), individual's beliefs are formed through subjective interpretation and evaluation of his/her experience, feedback and behavior of others. In other words, individual is a product of social relations, thus, his/her behavior is predicted by social interactions and relationship with other members of a particular community. Hence, teacher's self-efficacy depends on the behavior of school environment, therefore, should be investigated not only through personal, but also through collective perspective. Collective efficacy of teachers - teacher's perception of capability of their school to successfully accomplish common objectives and cope with challenges, and judgement about whether other members of educational process (colleagues, principal, students, parents) meet their obligations and contribute to common progress (Caprara et al., 2003).

Comparative analysis provides an opportunity for quantitative measurement and visualization of the current Ukrainian, Lithuanian and Finnish teachers' self-confidence levels and answers the research questions:

1. Is there a significant difference between Lithuanian, Ukrainian and Finnish teachers' perceptions of professional self-worth?

2. Is there a significant difference between Lithuanian, Ukrainian and Finnish teachers’ perceptions of professional self-efficacy? 
3. Is there a significant difference between Lithuanian, Ukrainian and Finnish teachers' perceptions of collective efficacy?

4. What are the degrees to which school constituencies meet their obligations (according to Lithuanian, Ukrainian and Finnish teachers' subjective evaluation)?

\section{Methodology}

In order to compare the opinions of larger samples of teachers, the quantitative strategy of inquiry was applied. The letters with a request for participation were sent directly to teachers of Lithuania, Ukraine and Finland. Their e-mail addresses were taken from the official school websites, which were chosen randomly or conveniently. The letters contained information about the researcher, purpose of study, ethical obligations and a link to the on-line questionnaire. The requests for participation in the research and questionnaires were translated into local languages by native speakers and language translators in order to ensure maximum similarity with the original and convenience for participants. Data collection period 15.09.2016 -15.04.2017.

\section{Participants}

Participants were 393 practicing teachers from schools in Lithuania, Ukraine and Finland. Samples were unequal in terms of the number of respondents: Lithuanian sample was the largest $(n=160)$, Ukrainian was smaller $(n=135)$ and Finnish sample was the smallest $(n=98)$. The largest part of schools was drawn randomly, embracing diverse regions of every country. Research was not focused on some particular groups of teachers; thus, the samples were diverse according to the school size, location, teachers' gender, age, years of experience or teaching fields. Only one condition was applied: teachers had to be employed in schools of Ukraine, Lithuania or Finland at the moment of participation in the research. The summary of the most important demographic information is provided in Table 1.

On the whole, samples from three countries were different in terms of gender, age and experience of participants. Lithuanian and Finnish samples had similarities in terms of teachers' experience rates as the largest number of participants had more than 16 years of teaching experience, while Lithuanian and Ukrainian samples were similar in terms of gender distribution - low number of male participants. 
Table 1. Demographic data of the Lithuanian, Ukrainian and Finnish samples

\begin{tabular}{ccccc}
\hline Variable & & Lithuania & Ukraine & Finland \\
\cline { 3 - 5 } & & Percent & Percent & Percent \\
\hline Gender & Female & 86.9 & 94.1 & 69.4 \\
& Male & 13.1 & 5.9 & 30.6 \\
\hline Years of & Less than 5 & 3.1 & 23.7 & 15.3 \\
experience & $6-15$ & 20.0 & 43.7 & 31.6 \\
& $16-25$ & 29.4 & 18.5 & 28.6 \\
& 25 and more & 14.1 & 14.1 & 24.5 \\
\hline
\end{tabular}

Lithuania $n=160$, Ukraine $n=135$, Finland $n=98$

\section{Instrument}

Teachers' professional self-esteem was measured with the questionnaire "Self-Esteem as Teachers Scale" (SET) adapted for teachers from Rosenberg's Self-Esteem Scale (Rosenberg et al., 1979) by Gibbs (Gibbs, 1994). The SET scale consists of 10 statements, where 5 statements reflect teachers' positive beliefs about their professional worth (i.e. satisfaction with self as a teacher, possession of good professional qualities, being proud of self, equal with colleagues, having positive attitude towards self as a teacher in general, etc.) and 5 statements reflect teachers' negative perceptions of their own professional self-worth (dissatisfaction with self as a teacher, feeling useless in working environment, desire for more respect, feeling of failure, etc.). Each item was measured using a 4-point Likert scale, ranging from 1 (strongly disagree) to 4 (strongly agree).

Teachers' perceived self- and collective efficacy was measured with a questionnaire, developed and validated by Caprara, Barbanelli, Borgogni and Steca (2003). The questionnaire contains 42 items and measures 6 different constructs of teachers' efficacy: self-efficacy (12 items), collective efficacy (9 items) and efficacy of school constituencies - principal (7 items), colleagues (6 items), students (4 items) and their parents (4 items). For each item teachers used a 7-point Likert scale, ranging from 1 (strongly disagree) to 7 (strongly agree).

\section{Data analysis}

The collected numeric data was exported from the on-line questionnaire directly to SPSS program, coded and described quantitatively using descriptive analysis (frequencies in demographical data, mean for each statement). In order to interpret the mean of self-esteem, a reverse coding for items 2, 5, 6, 8, 9 of SET questionnaire was used, as they reflected negative statements. All data was united into one file, and, using the function of computing variables, was divided into separate parts: self-worth, selfefficacy, collective efficacy, principals, colleagues, parents and students. These items were determined as dependent variables, and their means were 
calculated, while countries (Ukraine, Lithuania and Finland) were determined as independent variables. Multivariate linear model comparison (Scheffe test) was applied in order to compare the means of self-esteem, selfand collective efficacy across Lithuanian, Ukrainian and Finnish data and define the significance of differences between countries.

\section{Results}

Professional self-esteem of Lithuanian, Ukrainian and Finnish teachers

Positive professional self-worth beliefs. The results presented in Table 2 demonstrate general positive self-worth beliefs of teachers. The average means are higher than point 3 (which means "Agree" in the scale ranging from 1 to 4); thus, Lithuanian, Ukrainian and Finnish teachers have a positive attitude toward themselves as teachers. However, Finnish teachers scored their positive professional self-worth beliefs significantly higher $(\mathrm{M}=3.51)$ than Ukrainian $(\mathrm{M}=3.06)$ and Lithuanian teachers $(\mathrm{M}=3.35)$, and the difference is significant at 0.5 level. While Lithuanian teachers demonstrated the middle score of professional self-worth, which is higher than Ukrainian and lower than Finnish.

Table 2. Multivariate comparisons of Lithuanian, Ukrainian and Finnish teachers' professional self-worth (mean and Scheffe test)

\begin{tabular}{|c|c|c|c|c|c|c|}
\hline $\begin{array}{c}\text { Dependent } \\
\text { Variable }\end{array}$ & $\begin{array}{l}\text { Country } \\
\text { (I) }\end{array}$ & Mean & SD & $\begin{array}{l}\text { Country } \\
(\mathrm{J})\end{array}$ & $\begin{array}{c}\text { Mean } \\
\text { Difference } \\
\text { (I-J) }\end{array}$ & Sig. \\
\hline \multirow{6}{*}{$\begin{array}{l}\text { Positive } \\
\text { self-worth } \\
\text { beliefs }\end{array}$} & \multirow[t]{2}{*}{ Lithuania } & \multirow[t]{2}{*}{3.35} & \multirow[t]{2}{*}{.399} & Ukraine & $.29^{*}$ & .000 \\
\hline & & & & Finland & $-.17^{*}$ & .005 \\
\hline & \multirow[t]{2}{*}{ Ukraine } & \multirow[t]{2}{*}{3.06} & \multirow[t]{2}{*}{.406} & Lithuania & $-.29^{*}$ & .000 \\
\hline & & & & Finland & $-.46^{*}$ & .000 \\
\hline & \multirow[t]{2}{*}{ Finland } & \multirow[t]{2}{*}{3.51} & \multirow[t]{2}{*}{.392} & Ukraine & $.17^{*}$ & .005 \\
\hline & & & & Lithuania & $.46^{*}$ & .000 \\
\hline \multirow{6}{*}{$\begin{array}{c}\text { Negative } \\
\text { self-worth } \\
\text { beliefs }\end{array}$} & \multirow[t]{2}{*}{ Ukraine } & \multirow[t]{2}{*}{1.88} & \multirow[t]{2}{*}{.559} & Ukraine & $-.21^{*}$ & .003 \\
\hline & & & & Finland & $.24^{*}$ & .002 \\
\hline & \multirow[t]{2}{*}{ Lithuania } & \multirow[t]{2}{*}{2.09} & \multirow[t]{2}{*}{.505} & Lithuania & $.21^{*}$ & .003 \\
\hline & & & & Finland & $.45^{*}$ & .000 \\
\hline & \multirow[t]{2}{*}{ Finland } & \multirow[t]{2}{*}{1.64} & \multirow[t]{2}{*}{.488} & Ukraine & $-.24^{*}$ & .002 \\
\hline & & & & Lithuania & $-.45^{*}$ & .000 \\
\hline
\end{tabular}

Scale 1-4

*. The mean difference is significant at the .05 level.

Negative professional self-worth beliefs. Lithuanian and Finnish respondents indicated relatively low negative self-worth beliefs (lower than 2 in the scale ranging from 1 to 4 ), what means disagreement with negative view on self as a teacher, while Ukrainian teachers scored the highest in their negative view of selves as teachers. However, the comparison of means shows that the lowest negative beliefs were scored by Finnish teachers $(\mathrm{M}=1.64)$, while Lithuanian teachers scored higher (mean=1.88), and 
Ukrainian teachers' negative beliefs were the highest $(M=2.09)$, being in the border between agreement and disagreement. Multiple comparisons indicated a statistically significant difference $(p<.05)$, meaning that Ukrainian teachers have the highest level of negative professional self-worth beliefs, while Lithuanian - the middle, and Finnish teachers - the lowest.

\section{Professional self-efficacy of Lithuanian, Ukrainian and Finnish teachers}

The implementation of the descriptive statistics and comparison of means demonstrated differences between Lithuanian, Ukrainian and Finnish teachers' professional self-efficacy (Table 3). The Finnish teachers scored the highest rates $(M=5.74)$ in overall attitudes towards their professional selfefficacy, while Lithuanian teachers' average self-efficacy means were lower than Finnish ( $M=5.55)$, and higher than Ukrainian $(M=5.09)$. At the same time, all means scored by teachers indicated positive evaluation of their professional self-efficacy (higher than 5 of a scale ranging from 1 to 7), meaning that teachers agree with their efficiency, performativity and capability to achieve professional success encountering demanding situations or tasks. Multiple comparison (Scheffe test) was implemented and results indicated that Ukrainian teachers scored significantly lower (at the .05 level) comparatively to Lithuanian (-.46) and Finnish teachers (-.66), while the difference between Lithuanian and Finnish teachers' self-efficacy was statistically insignificant, meaning that they experience similar beliefs about their professional self-efficacy.

Table 3. Lithuanian, Ukrainian and Finnish teachers' professional self-efficacy: multiple comparisons (Scheffe test)

\begin{tabular}{ccccccc}
\hline $\begin{array}{c}\text { Dependent } \\
\text { variable }\end{array}$ & $\begin{array}{c}\text { Country } \\
(\mathrm{I})\end{array}$ & Mean & SD & $\begin{array}{c}\text { Country } \\
(\mathrm{J})\end{array}$ & $\begin{array}{c}\text { Mean Difference } \\
(\mathrm{I}-\mathrm{J})\end{array}$ & Sig. \\
\hline Self-efficacy & Lithuania & 5.55 & .733 & Ukraine & $.46^{*}$ & .000 \\
& & & & Finland & -.19 & .159 \\
\cline { 2 - 7 } & Ukraine & 5.09 & .933 & Lithuania & $-.46^{*}$ & .000 \\
& & & & Finland & $-.66^{*}$ & .000 \\
\cline { 2 - 7 } & Finland & 5.74 & .586 & Lithuania & .19 & .159 \\
& & & Ukraine & $.66^{*}$ & .000 \\
\hline
\end{tabular}

Scale 1-7

The mean difference is significant at the .05 level.

Lithuania $n=160$, Ukraine $n=135$, Finland $n=98$.

\section{Collective efficacy of Lithuanian, Ukrainian and Finnish teachers}

Collective efficacy. Table 4 demonstrates that Lithuanian and Finnish teachers scored significantly higher level of collective self-efficacy than Ukrainian teachers $(\mathrm{p}<.05)$. The average mean of teachers' beliefs in school capacities to achieve common goals was indicated highly by Lithuanian teachers $(M=5.51)$, and the result of Finnish teachers was insignificantly 
lower ( $M=5.32)$. The Ukrainian teachers' collective efficacy beliefs were significantly lower $(M=4.84)$, however, remained positive (above average of the scale from 1 to 7 , where 4 is a point of uncertainty). The results indicated differences in teachers' perceptions of school efficiency and capability to perform; however, some similarities between teachers' opinions were defined. Teachers indicated the highest scores for the capability of their school to earn the prestige within the community, at the same time the lowest scores were given for schools' capability to obtain parents' engagement and collaboration, which means teachers' uncertainty.

Table 4. Lithuanian, Ukrainian and Finnish teachers' collective efficacy: means and multiple comparisons

\begin{tabular}{|c|c|c|c|c|c|c|}
\hline $\begin{array}{l}\text { Dependent } \\
\text { variable }\end{array}$ & $\begin{array}{l}\text { Country } \\
\text { (I) }\end{array}$ & Mean & SD & $\begin{array}{c}\text { Country } \\
(\mathrm{J})\end{array}$ & $\begin{array}{c}\text { Mean Difference } \\
\text { (I-J) }\end{array}$ & Sig. \\
\hline \multirow{6}{*}{$\begin{array}{l}\text { Collective } \\
\text { efficacy }\end{array}$} & Lithuania & 5.51 & .906 & Ukraine & $.67^{*}$ & .000 \\
\hline & & & & Finland & .19 & .334 \\
\hline & Ukraine & 4.84 & 1.21 & Lithuania & $-.67^{*}$ & .000 \\
\hline & & & & Finland & $-.48^{*}$ & .001 \\
\hline & Finland & 5.32 & .717 & Lithuania & -.19 & .334 \\
\hline & & & & Ukraine & $.48^{*}$ & .001 \\
\hline
\end{tabular}

Scale 1-7

The mean difference is significant at the 0.05 level.

Lithuania n=160, Ukraine n=135, Finland n=98.

Constituencies of collective efficacy. The analysis of school constituencies' efficacy demonstrated particularly how principals, colleagues, students and their parents meet their obligations and perform according to teachers' subjective evaluations and expectations (Figure 2).

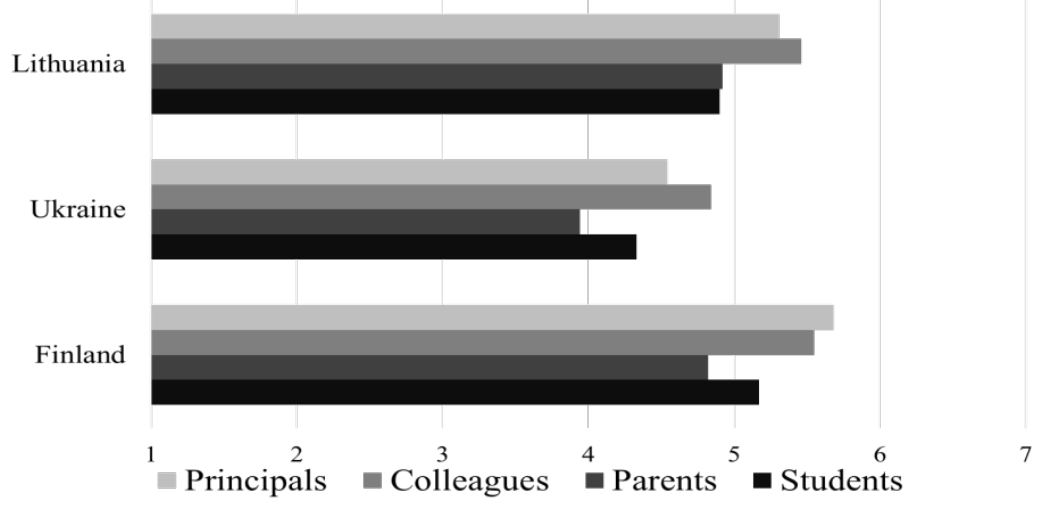

Figure 2. Efficiency of school community members

On the whole, Ukrainian teachers evaluated the performance and efforts of school community members significantly lower than Finnish and Lithuanian teachers (at the .05 level). The efficiency of students and their 
parents in execution of their duties at school was evaluated the lowest by teachers from all three countries $(\mathrm{M}=4.77$ and $\mathrm{M}=4.56$ accordingly in a scale from 1 to 7) meaning teachers' uncertainty. At the same time, the efficiency of colleagues in the execution of their duties was evaluated the highest $(M=5.26)$. Evaluation of principals' efficacy was different - Finnish and Lithuanian teachers evaluated their principals' efficacy significantly higher, comparatively to Ukrainian.

\section{Discussion}

The main goal of the current research was to investigate the difference between average degrees of Lithuanian, Ukrainian and Finnish teachers' professional self-confidence, measuring teachers' self-worth (esteem), self- and collective efficacy. In general, the findings indicated that Finnish teachers have a significantly higher level of professional self-worth, comparatively to Lithuanian and Ukrainian teachers, however, the self- and collective efficacy of Finnish teachers is similar to Lithuanian. At the same time, Ukrainian teachers have the lowest degrees of self-worth, self and collective efficacy, comparatively to both Finnish and Lithuanian teachers. Therefore, comparing teachers' self-esteem, self-efficacy and collective efficacy beliefs, Finnish teachers have the highest level of professional selfconfidence, while Lithuanian teachers are in the middle (due to significantly lower self-worth beliefs), and Ukrainian teachers have the lowest level of professional self-confidence among the three countries investigated. Probable reasons and consequences of these differences are discussed below.

Professional self-worth refers to teacher's attitude towards self as a professional, evaluation of his/her self-worthiness and efficiency within the working environment. As it was mentioned before, Finnish teachers indicated relatively the highest level of professional self-worth about positive beliefs and the lowest about negative beliefs. In other words, Finnish teachers believe they are good as teachers, having sufficient professional qualities, positive attitude towards self as a teacher and believe being respected by others. The possible explanation of such a high rate might be that Finnish teachers are identified with the upper social strata (Simola, 2005), and have a strong sense of professional commitment due to high quality of higher education and selection procedures to become teachers. Moreover, teacher's profession is highly respected by the society, being one of the most desirable for students to enter, and only 10-15\% of teachers leave the profession (Sahlberg, 2013). Professional commitment, competence and persistence were defined by Hoyle (2001) as important sources of occupational self-esteem. At the same time, Lithuanian and Ukrainian teachers are more inclined to think about their own failure as teachers and desire of more external respect from others. For instance, both Lithuanian 
and Ukrainian teachers pointed a high level of agreement with the statement "I wish I could have more respect for myself as a teacher", while Finnish teachers mostly disagreed with the same statement. However, the question of lack of respect towards teachers needs a further qualitative investigation, as it remains unclear who teachers desire more respect from - particular people, groups of people or society as a whole. Teachers' professional self-esteem may be shaped by school surrounding in form of feedback from colleagues, principal or students' parents (social persuasion) (Bandura, 1995). For instance, both Lithuanian and Ukrainian teachers expressed their uncertainty in a question about students' respectful attitude towards teachers and school environment, thus, students might be one of the possible sources of teachers' concerns about lack of respect. Another possible explanation of similarity in Lithuanian and Ukrainian teachers' self-worth appraisal may be the fact that both, Lithuania and Ukraine, were parts of the Soviet Union and experienced strong influence of its ideology. Education was highly esteemed in the Soviet times, and this view is still present in the society, especially among older generation. For this reason, teaching was an admirable and very prestigious profession. Teachers had a high status within the society, and the authoritarian model of relationship with students was accepted and desired. But nowadays a student-centered approach in education has changed the demands for teachers' behavior - they should take into consideration children and family needs, being providers of educational service. This shift from the past to modernity in the role of a teacher may be an explanation why Ukrainian and Lithuanian teachers desire more external respect.

At the same time, Ukrainian teachers have significantly higher negative beliefs about their own self-worth comparing to Lithuanian and Finnish teachers. It may be caused by low financial rewards, the feminization of the teaching profession, lowering profession's status and dramatic decrease in value of the teaching profession in Ukraine (Vitrukh, 2014). In addition, it is a reason of high rates of leaving the teaching profession and a decrease in the sense of commitment to teach.

The difference between Lithuanian and Finnish teachers' professional self-worth beliefs is, perhaps, rooted in the teachers' initial selection, level of salaries, prestige and attractiveness of teaching profession in both countries. Lithuanian teachers believe their profession is not attractive for youth and has a low prestige within the society, despite the attempts of government to enhance teachers' status. Moreover, due to the lack of students in schools, especially in rural areas, there is a lack of workload (less than 18 hours per week), so teachers are forced to have a second job, which causes declination of quality of working conditions, decreases teachers' job satisfaction, and, as a result, - decreases their professional self-efficacy, self-worth and professional self-confidence (Shewbridge et al., 2016). While in Finland 
teaching remains one of the most admirable and desirable professions with high social status and prestige. One of the main differences is teachers' selection - in Finland only $10 \%$ of school graduates with the highest achievements after national Matriculation examination can enter the teaching profession (for instance, only 5000 teachers out of 20000 applicants were selected to become teachers in 2011) (OECD report, 2012). Therefore, only highly motivated and efficacious students are recruited into Finnish schools to become teachers, and their high scores about their own self-worth are expected To compare - Lithuanian government attracts high-achievers providing them with scholarships to enroll into teaching studies; however, $85 \%$ of graduates have doubts if they want to enter a teaching profession, thus, only insignificant part of young (3\% aged till 30) teachers work at Lithuanian schools nowadays (Shewbridge et al., 2016).

In general, the professional self-efficacy was evaluated positively by Lithuanian, Ukrainian and Finnish teachers. However, the research findings indicated a significant difference between self-efficacy beliefs - the lowest level was indicated by Ukrainian teachers comparing to Finnish and Lithuanian. Such results might be explained by the unequal distribution of different age categories - years of teaching experience have influence on teachers' self-efficacy, when young teachers usually have lower level of selfefficacy due to the lack of mastery experience (Tschannen-Moran, 1998; Klassen \& Chiu, 2010). The Ukrainian sample consisted mostly of young teachers aged from 20 to 30 (44\% from total number), who may have approximately from 0 to 10 years of teaching experience, while Finnish and Lithuanian samples consisted of teachers aged from 41 to 60, with higher teaching experience (from 16 to 25 years).

Teachers' self-efficacy is linked with their job satisfaction and professional autonomy (Klassen \& Chiu, 2010). Finnish teachers have a high level of professional autonomy, freedom in teaching and absence of external evaluation of their performativity (Simola, 2005; Sahlberg, 2013). High evaluation of professional efficiency by both Lithuanian and Finnish teachers may be caused by relatively small class sizes (Finnish average class size 18, Lithuanian - 20 pupils). It creates more favorable working conditions, enhances teachers' job satisfaction, making classes more manageable, thus, increases teachers' professional self-efficacy. Moreover, teachers' professional development is well-organized and developed in both countries (OECD report, 2012; Shewbridge et al., 2016). While there is a tendency in Ukrainian schools to increase school class size up to 38 pupils, at the same time, Ukrainian educational system is still highly centralized and there is a little teaching freedom within educational organizations - teachers have few opportunities to participate in decision-making processes or to introduce changes into the curriculum (Vitrukh, 2014). As a consequence, Ukrainian 
teachers may work less efficiently and demonstrate less professional commitment.

Ukrainian teachers rated their collective efficacy the lowest. It may be explained by the same reason - the sample differences in years of teaching experience, at the same time indicate the interrelation between selfand collective efficacy. While high level of Finnish teachers' collective efficacy may be explained by high level collaboration between teachers during creation of educational programs and courses. Collective efficacy is a predictor of high students' achievement and motivation to study (Skaalvik \& Skaalvik, 2007). There are low percentages of pupils who repeat the grade in Finnish and Lithuanian schools (3 and 2 \% accordingly) (OECD, 2015), what may be linked with high teachers beliefs about professional selfefficacy and collective efficacy of their school communities. While uncertainty of Ukrainian teachers about the efficiency of their schools demonstrates their inability and shortage of cooperation skills, abilities to plan common goals and courses, accounting desires of others and trust in capabilities of school.

Ukrainian teachers indicated an uncertainty about efficacy of colleagues, principal and students and negatively evaluated parents' efficacy. The reasons, perhaps, are rooted in the insufficient actual collaboration between teachers, absence of common projects and large power distance between members of school community - the obedience rather than cooperation in school hierarchy is expected. Lithuanian teachers rated the highest scores for efficacy of colleagues and principal, and the lowest - for parents and students, which indicates the problems in teacher-parents and teacher-student relations. The relationship between parents, students and teachers must be fostered and enhanced by ensuring purposeful deep cooperation.

High evaluation of principals’ efficacy and trust in their capacities for common educational goals accomplishment may be explained by mutual equality and cooperation of teaching staff and principal in Finnish schools. Principals are part of teachers' collective, pedagogical staff rather than administrators, because leadership is tightly connected to teaching in Finnish schools. Principals usually teach some subjects, cooperating with teachers, and it leads to the establishment of trust-based professional relationship (Sahlberg, 2013). Low points for parents' efficacy, perhaps, relate to the shortage of communication between parents and teachers. On the one hand, Finnish teachers, being pedagogically conservative, build official relationship with parents, often keep "professional distance" from their pupils and their home problems. On the other hand, Finnish teachers enjoy the high trust from parents' community, and $86 \%$ of parents are satisfied with teachers' work (Simola, 2005), which may lead to a low level of 
parents' participation in educational process, as they completely rely on teachers, and thus, teachers dissatisfaction with parents' participation.

Limitations. The present study has several limitations. First, teachers participated in the survey voluntarily, and valuable feedback from the participants who rejected to complete the survey might be missed. Second, the current study relied on self-report, where teachers might not have answered truthfully but instead reported how they believe they should be doing. And a small number of participants may not show the comprehensive picture of the actual situation in the countries.

\section{Conclusion}

The current research is valuable in terms of its theoretical and practical contribution to the investigation of teachers' professional selfconfidence. The investigation and measurement of Lithuanian, Ukrainian and Finnish teachers' professional self-confidence creates a picture of possible strengths and weaknesses in the work of each school system and provides a possibility to understand the different conditions of teachers' work. Differences in teachers' opinions may be caused by cultural, historical or economic reasons.

Further qualitative investigation and interviewing of teachers may answer the questions, aroused by the current quantitative study: How do teachers understand the notion of professional self-confidence and its importance? What other external or internal factors influence their professional self-confidence? Why do Lithuanian and Ukrainian teachers desire more respect, while Finnish do not? Which ways of professional selfconfidence enhancement teachers believe are reasonable?

\section{Acknowledgements}

Author would like to thank dr. Terese Ringailiene, dr. Helena Hulmi, prof. Ismo Pelikka, prof. Paul Fryer, Svitlana Pazychenko and Henna Paananen for their support and assistance in translations and data collection.

\section{References:}

1. Bandura, A. (1977). Self-efficacy: toward unifying theory of behavioral change. Psychological review, 84(2), 191-215.

2. Bandura, A. (1995). Exercise of personal and collective efficacy in changing societies. In A. Bandura (Eds.), Self-efficacy in Changing Societies (pp. 1-45). New York, NY: Cambridge University Press.

3. Caprara, G.V., Barbaranelli, C., Borgogni, L., \& Steca, P. (2003). Efficacy beliefs as determinants of teacher job satisfaction. Journal of educational psychology, 95(4), 821-832. 
4. Carroll, P.J., Arkin, R.M., \& Shade, C.K. (2011). Possible selves and self-doubt: a poverty of desired possibility. Social Psychological and Personality Science, 2(2), 190-198.

5. Cheung, H-Y. (2006). The measurement of teacher efficacy: Hong Kong primary in-service teachers. Journal of Education for Teaching, 32(4), 435-451.

6. Clark, F. A. (2010). Power and confidence in professions: lessons for occupational therapy. Canadian Journal of Occupational Therapy, 77(5), 264-269.

7. Eison, J. (1990). Confidence in the classroom: ten maxims for teachers. College teaching, 38(1), 21-25.

8. Gecas, V. (1982). The self-concept. Annual Review of Sociology, 8(1), 1-33.

9. Gibbs, J.C. (1994). Teacher efficacy, orientations toward children and self-esteem: the effects of student teaching practice (Unpublished doctoral dissertation). Massey University, New Zealand.

10. Hargreaves, L., Cunningham, M., Hansen, A., McIntyre, D., Oliver, C., \& Pell, T. (2007). The status of teachers and the teaching profession: views from inside and outside the profession: interim findings from the teacher status project. Research Report RR831A, Cambridge: DfES.

11. Heatherton, T. F., \& Wyland, C.L. (2003). Assessing self-esteem. Positive psychological assessment. American Psychological Association, 14(3), 219-233.

12. Holland, K., Middleton, L., \& Uys, L. (2012). Professional confidence: a concept analysis. Scandinavian Journal of Occupational Therapy, 19, 214-224.

13. Hoyle, E. (2001). Teaching: prestige, status and esteem. Educational Management and Administration, 29(2), 139-152.

14. Khan, A., Fleva, E., \& Qazi, T. (2015). Role of self-esteem and general self-efficacy in teachers' efficacy in primary schools. Psychology, 6, 117-125.

15. Klassen, R.M., \& Chiu, M. M. (2010). Effects on teacher's selfefficacy and job satisfaction: teacher gender, years of experience, and job stress. Journal of educational psychology, 102(3), 741-756.

16. Miller, D. J., \& Moran, T. (2006). Positive self-worth is not enough: some implications of two-dimensional model of self-esteem for primary teaching. Improving Schools, 9(1), 7-16.

17. OECD (2012), "Finland: A Non-Competitive Education for a Competitive Economy”, in Lessons from PISA for Japan, OECD Publishing, Paris. 
18. Oney, E., \& Oksuzoglu-Guven, G. (2015). Confidence: a critical review of the literature and alternative perspectives for general and specific self-confidence. Psychological Reports: Mental \& Physical Health, 116(1), 149-163.

19. Paradis, A., Lutovac, S., \& Kaasila, R. (2015). A Canadian teacher's perceived autonomy and self-confidence in the midst of an educational reform. Problems of education in 21 century, 66(5), 4253.

20. Peng, A., Schaubroeck, J., \& Xie J.L. (2015). When confidence comes and goes: how variation in self-efficacy moderates stressorstrain relationships. Journal of Occupational Health Psychology, 20(3), 359-376.

21. Postareff, L., \& Lindblom-Ylanne, S. (2011). Emotions and confidence within teaching in higher education. Studies in Higher education, 36(7), 799-813.

22. Putman, S.M. (2012). Investigating teacher efficacy: comparing preservice and in-service teachers with different levels of experience. Action in Teacher Education, 34(1), 26-40.

23. Rosenberg, M., Schooler, C., \& Schoenbach, C. (1995). Global selfesteem and specific self-esteem: different concepts, different outcomes. American Sociological Review, 15(1), 141-156.

24. Sadler, I. (2013). The role of self-confidence in learning to teach in higher education. Innovations in Education and Teaching International, 53(2), 157-166.

25. Sahlberg, P. (2013). Teachers as leaders in Finland. Educational leadership, 12(1), 36-40.

26. Savolainen, H., Engelbrecht, P., Nel, M., \& Malinen, O-P. (2012). Understanding teachers' attitudes and self-efficacy in inclusive education: implications for pre-service and in-service teacher education. European Journal of Special Needs Education, 27(1), 5168.

27. Shewbridge, G. et al. (2016). OECD Reviews of School Resources: Lithuania 2016, OECD Reviews of School Resources, OECD Publishing, Paris.

28. Shrauger, J.S., \& Schohn, M. (1995). Self-confidence in college students: conceptualization, measurement and behavioral implications. Psychological Assessment Resources, 2(3), 255-278.

29. Simola, H. (2005). The Finnish miracle of PISA: historical and sociological remarks on teaching and teacher education. Comparative education, 41(4), 455-470.

30. Skaalvik, E., \& Skaalvik, S. (2007). Dimensions of teacher selfefficacy and relations with strain factors, perceived collective teacher 
efficacy, and teacher burnout. Journal of educational psychology, 99(3), 611-625.

31. Stets, J.E., \& Burke, P.J. (2014). Self-esteem and identities. Sociological Perspectives, 57(4), 409-433.

32. Tschannen-Moran, M., Woolfolk Hoy, A., \& Hoy, W.K. (1998). Teacher efficacy: its meaning and measure. Review of Educational Research, 68(2), 202-248.

33. Vitrukh, M. (2014). Exploratory study of the professional identity of higher education teachers in Ukraine. InterDisciplines, 2(1). 